\title{
Population structure of Eschweilera coriacea (DC.) S. A. Mori in forest fragments in eastern Brazilian Amazonia
}

\author{
MARIA APARECIDA LOPES ${ }^{1}$
}

(received: November 10, 2006; accepted: September 27, 2007)

\begin{abstract}
Population structure of Eschweilera coriacea (DC.) S. A. Mori in forest fragments in eastern Brazilian Amazonia). The population structure of a common canopy tree was examined in three sites to investigate the possible effects of forest fragmentation in eastern Amazonia. Evidence for the escape hypothesis of differential seed/seedling survival was evaluated. Two 1 ha plots were established at each site and all individuals of Eschweilera coriacea (DC.) S. A. Mori over $1 \mathrm{~m}$ tall were tagged, measured and mapped. Smaller individuals were recorded in the same way within subplots. Mature individuals were abundant at all sites with densities of 32-52 ha-1. The species exhibited substantial regeneration, although total population density varied fourfold among sites (1,256-4,805 individuals $\left.\mathrm{ha}^{-1}\right)$. Overall, juveniles were clumped while adults were randomly distributed. The difference between the dispersion pattern of adults and juveniles supported the escape hypothesis. However, no difference in population structure among sites could be related to the forest fragmentation.
\end{abstract}

Key words - dispersion pattern, escape hypothesis, forest fragmentation, Neotropical forest, population density

RESUMO - (Estrutura populacional de Eschweilera coriacea (DC.) S. A. Mori em fragmentos florestais no leste da Amazônia brasileira). A estrutura populacional de uma árvore de dossel comum na Amazônia oriental foi examinada em três áreas para investigar possíveis efeitos da fragmentação da floresta. Evidências para a hipótese de escape referente à sobrevivência diferenciada de sementes/plântulas foram avaliadas. Duas parcelas amostrais de um hectare foram estabelecidas em cada área e todos os indivíduos de Eschweilera coriacea (DC.) S. A. Mori acima de um metro de altura foram marcados, medidos e mapeados. Indivíduos menores foram registrados da mesma maneira em subparcelas. Indivíduos maduros foram abundantes em todas as áreas com densidades de 32-52 ha- ${ }^{-1}$ A espécie exibiu regeneração substancial, embora a densidade populacional tenha variado quatro vezes entre as áreas (1.256-4.805 indivíduos ha $\left.{ }^{-1}\right)$. Em geral, jovens apresentaram-se agregados enquanto adultos eram distribuídos aleatoriamente. A diferença no padrão de dispersão de adultos e jovens deu suporte à hipótese de escape. Entretanto, nenhuma diferença na estrutura da população entre as áreas pôde ser relacionada à fragmentação da floresta.

Palavras-chave - densidade populacional, floresta neotropical, fragmentação de floresta, hipótese de escape, padrão de distribuição

\section{Introduction}

In the past half century, development in the tropics has led to large-scale deforestation at unprecedented rates in the evolutionary context of tropical rain forests, which will have profound effects on these ecosystems (Bierregaard Junior et al. 1992). Although large undisturbed areas of tropical rain forest can still be found, only small patches remain in many regions, and these patches may constitute the only possibility of preserving these ecosystems (Turner \& Corlett 1996).

An increasing number of studies have demonstrated that human-induced changes to natural ecosystems, particularly deforestation and habitat fragmentation, result in significant alterations of distribution and

1. Universidade Federal do Pará, Instituto de Ciências Biológicas, Rua Augusto Corrêa 1, 66.075-110 Belém, PA, Brazil. maria@ufpa.br abundance of organisms. The susceptibility of a particular species to habitat disturbance is highly variable, however, and while many species decline or disappear, others remain unaffected or are even benefited (Tabarelli et al. 1999, Laurance et al. 2002, Lindenmayer et al. 2002).

Understanding ongoing processes in forest remnants may be of crucial importance for the management and conservation of natural systems (Bierregaard Junior $e t$ al. 1992). The processes involved in the regeneration of tree populations, including many plant-animal interactions, may be of particular interest, since they will ultimately determine the floristic composition of the remnants (Laurance et al. 1998). For instance, the recruitment of many tree species is animal-mediated, and the loss of seed-dispersal agents is likely to endanger tree species and affect community structure and dynamics (Cordeiro \& Howe 2001, Wright \& Duber 2001). However, the net effect of fragmentation on plant-animal interactions may have opposite outcomes, 
since it may disrupt beneficial relationships such as pollination and seed dispersal, and decrease antagonistic relationships such as seed predation at the same time (García \& Chacoff 2007).

The data presented here are part of a study that investigated the possible consequences for a common canopy tree (Eschweilera coriacea (DC.) S. A. Mori, Lecythidaceae) of the loss of potential seed dispersers due to forest fragmentation in eastern Brazilian Amazonia. A natural experimental approach was used in which the structure and dynamics of E. coriacea populations were compared at three sites.

Recruitment shortfalls in a tree population can occur at different life history stages, including the arrival of the seeds on the ground, which depends, in turn, on the density and dispersion of adults, adult fecundity, and seed dispersal distances (Clark et al. 1998). In this paper, I describe the density, dispersion and population size structure of E. coriacea at the three sites, and test the escape hypothesis which postulates disproportionate mortality of progeny near parent plants, caused by distance- or density-responsive seed predators, herbivores, or pathogens (Janzen 1970, Connell 1971, Howe \&
Smallwood 1982, Clark \& Clark 1984, Nathan \& Casagrandi 2004). Data on other life stages and population processes are reported elsewhere.

I aim to answer the following questions: 1) Do the dispersion patterns of juveniles, adults and the population as a whole differ among themselves? 2) How do the densities of adults and juveniles vary with distance from individual trees? 3) Are dispersion and abundance patterns in the small forest fragment significantly different from those at the other sites? In addition to characterising the population structure of E. coriace $a$ at the three sites, questions 1 and 2 evaluate the escape hypothesis, whereas among-site comparisons (question 3 ) are relevant to investigate possible effects of habitat fragmentation on population structure of Eschweilera coriacea.

\section{Material and methods}

Study sites - The three study sites are located in the Brazilian state of Pará, in the easternmost extreme of the Amazonian biome (figure 1). The climate of the three sites is relatively similar (Köppen's Am category), although there is a northsouth gradient of decreasing precipitation, which correlates

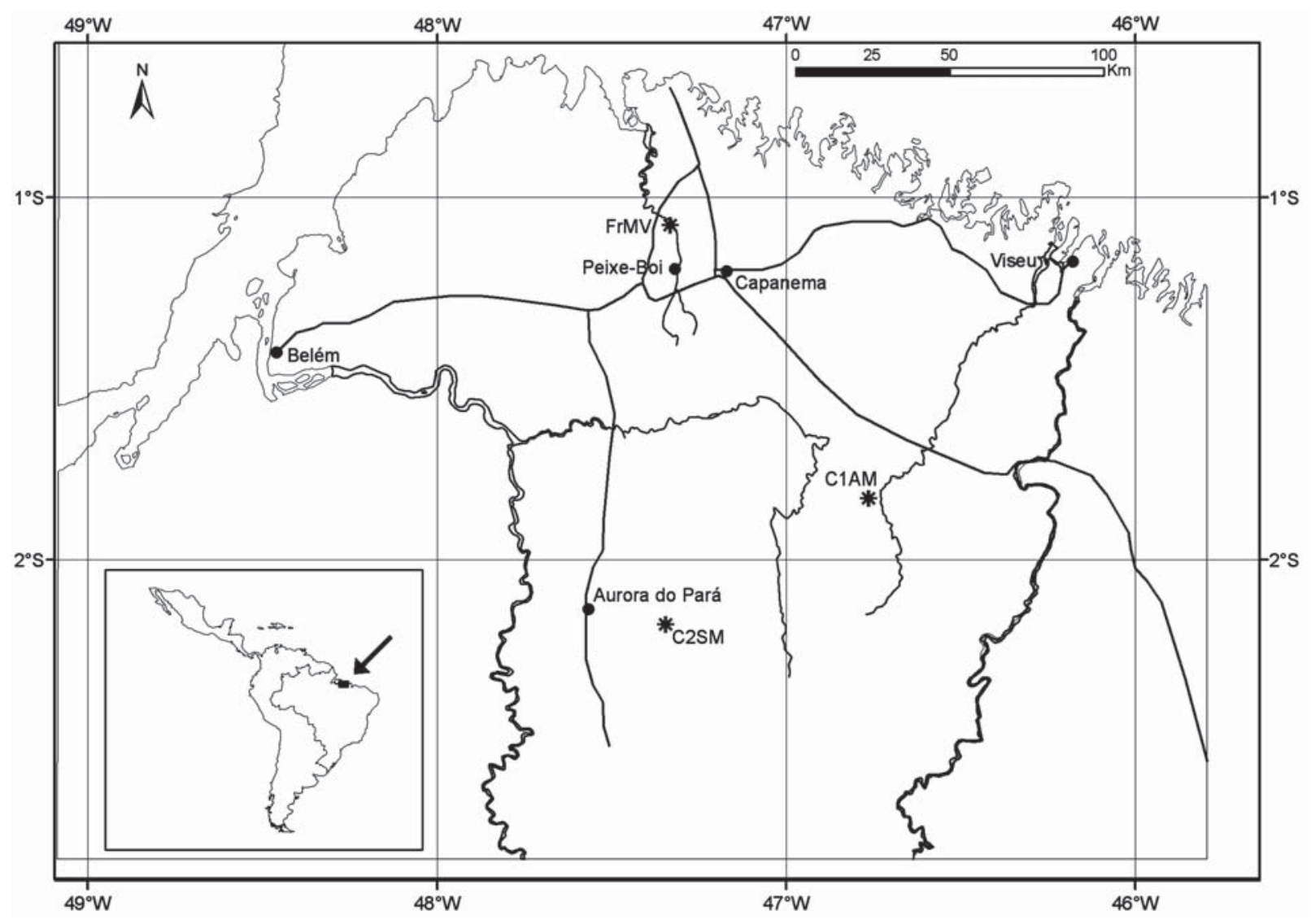

Figure 1. Location of the study sites in eastern Brazilian Amazonia. 
with increasing distance from the coast (SUDAM 1984, Diniz 1986, Guimarães et al. 2001). Mean annual temperature at all three sites is $25-27^{\circ} \mathrm{C}$, mean annual precipitation is 2,000$2,500 \mathrm{~mm}$ and average relative humidity is $80 \%-85 \%$ (Oliveira et al. 2002). The rainiest trimester is February to April and the driest is September to November (Guimarães et al. 2000). The predominant soil type is yellow latosoil (Silva \& Carvalho 1986), and the original vegetation was primarily lowland "terra firme" rainforest (Prance 1989, Veloso et al. 1991).

The site at the "Fazenda Monte Verde" (FrMV) in the municipality of "Peixe-Boi" ( $\left.1^{\circ} 11^{\prime} \mathrm{S}, 47^{\circ} 19^{\prime} \mathrm{W}\right)$ is a 200 ha forest fragment of prevailing "terra firme" forest that has been isolated for at least forty years. The region has already lost at least eighty five percent of its original forest cover, resulting in a mosaic landscape of pastures, cultivated fields, secondary forest and remnant patches of primary forest, of which FrMV is the largest (Alencar et al. 1996, Vieira et al. 1996). FrMV has lost most of its larger mammalian fauna, including three mediumsized primates and all of its ungulates (Lopes \& Ferrari 2000).

The second study site, a 1,200 ha forest reserve at the "Fazenda Amanda" $\left(\mathrm{C}_{1} \mathrm{AM}\right)$ in the municipality of Viseu $\left(1^{\circ} 50\right.$ ' S, $46^{\circ} 45^{\prime} \mathrm{W}$ ), is part of a fragment of approximately 3,500 ha of predominantly "terra firme" forest. Viseu contains a similar mosaic landscape to that observed at "Peixe-Boi", although there are relatively large forest remnants in its southern extreme, where "Fazenda Amanda" is located. The diurnal mammal community at the site appears to be relatively intact (Pereira 2002).

The third area is a reserve of approximately 3,600 ha of "terra firme" forest at the "Fazenda São Marcos" $\left(\mathrm{C}_{2} \mathrm{SM}\right)$, in the municipality of "Aurora do Pará" ( $2^{\circ} 13^{\prime}$ S, $47^{\circ} 20^{\prime}$ W). Until 1993, this reserve was part of a forest fragment of 10,000 ha, the majority of which was felled for agriculture, leaving only the study site and a separate 1,000 ha fragment. Prior to fragmentation, the mammalian fauna at this site was apparently intact (Lopes \& Ferrari 2000), and recent observations indicate that most species are still present. Given their characteristics, these two larger fragments are considered to be control sites in the present study, for comparisons with FrMV.

Study species - Eschweilera coriacea is a common canopy tree up to $37 \mathrm{~m}$ tall, widely distributed in the Amazon basin, and occurs at high densities in eastern Amazonia (Nelson \& Oliveira 2001, and references therein). It is most abundant in "terra firme" forest, but is also found in seasonally-flooded "várzea" and "igapó" up to 1000 m above sea level (Pires \& Prance 1977).

The species's fruit is a medium-sized woody pyxidium measuring 5-7 $\times 3.5-8 \mathrm{~cm}$ that contains one to several large 25-30 $\times 15-20 \mathrm{~mm}$ - seeds (Mori \& Prance 1990). As in most lecythid species, the fruit remains fixed to the tree until the seeds are released. There is no fleshy pulp, but seeds have well-developed lateral funicle-arils that may attract some frugivorous animals, such as large birds and bats. Seeds are dropped in large numbers directly under parent trees. Gravity plays a role in their dispersal and vertebrate consumers such as rodents and primates may also disperse seeds (Prance \& Mori 1978, Mori \& Prance 1990, personal observation).
Sampling design - Two randomly selected one hectare plots $(100 \times 100 \mathrm{~m})$ were established at each study site to estimate the abundance, size class structure and dispersion patterns of E. coriacea. Each plot was divided into one hundred $10 \times$ $10 \mathrm{~m}$ quadrats demarcated with wooden stakes at each corner. All individuals of $E$. coriacea with a stem height of at least one metre were tagged, measured (stem diameter) and mapped to the nearest centimeter. Distances to the two closest grid stakes were measured and used to locate each plant on a map of the plot. Stem diameter was measured at soil level (das) for plants $<2 \mathrm{~m}$ in height, and at breast height (dbh: $1.3 \mathrm{~m}$ ), or above buttresses, for those $>2 \mathrm{~m}$.

All individuals $<1 \mathrm{~m}$ in height were sampled in eleven $2 \times$ $100 \mathrm{~m}$ transects per plot. Each of these transects was divided into $1 \times 5$ m quadrats to which individuals were assigned. For mapping, the location of each individual was considered to be the centre of the quadrat to which it was assigned.

The minimum size of adults was determined by monitoring flowering and fruiting of 499 trees $(\mathrm{dbh} \geq 10 \mathrm{~cm})$ for two years in the six study plots and three other one-hectare plots, two at FrMV and one at $C_{1} A M$. Only individuals with $\mathrm{dbh} \geq 14 \mathrm{~cm}$ fruited during the study.

Data analyses - Structural characteristics (size class structure, dispersion and density) were determined and compared among sites. To visualise the size class structure at each site, the number of individuals in transect samples (individuals $<1 \mathrm{~m}$ in height) was scaled to 1 ha and combined with individuals with $\mathrm{dbh}<1$ $\mathrm{cm}$. The rest of the population was grouped in doubling size classes (dbh up to $2 \mathrm{~cm}, 4 \mathrm{~cm}, 8 \mathrm{~cm} .$. ), following Preston (1948, in Hubbell 2001). Differences among sites in size class population structure were evaluated using the Kolmogorov-Smirnov goodness-of-fit test (Sokal \& Rohlf 1995, Ayres et al. 2005).

Dispersion patterns were evaluated using standardised Morisita's index of dispersion $\left(I_{p}\right)$ (Krebs 1999). The effect of quadrat size on the spatial distribution patterns detected was examined by calculating the index for different quadrat sizes. For individuals $\geq 1 \mathrm{~m}$ tall, quadrat sizes of $100,200,400,900$, 1,600 and 2,500 $\mathrm{m}^{2}$ were tested. Quadrat sizes tested for individuals $<1 \mathrm{~m}$ tall $-5,10,20,40,50,100$ and $200 \mathrm{~m}^{2}$ (an entire transect) - were different due to the alternative sample design for this size class. Differences in dispersion patterns between plots within a site and among sites were tested with the Kruskal-Wallis nonparametric analysis of variance. To determine which of the samples differed significantly, multiple comparisons were performed following Dunn's procedure (Zar 1999, Ayres et al. 2005).

Spatial patterns of E. coriacea at the three sites were also evaluated using Condit et al. (2000) relative neighbourhood density or $\Omega$, which examines the distribution of conspecifics around each individual within the plots. $\Omega$ was used to compare dispersion patterns of $E$. coriacea among plots and sites, and to examine neighbourhood differences between juveniles $(\geq 1 \mathrm{~m}$ tall) and adults. All calculations were run in a Matlab program written by L. Sternberg (unpublished).

Distance intervals were $5 \mathrm{~m}$-wide concentric rings ( 0 to $5 \mathrm{~m}, 5$ to $10 \mathrm{~m}$, and so on), a value chosen based on the mean 
crown radius recorded for a sample of adult trees ( 13 individuals, 4 measurements for each tree $[n=52]$, mean crown radius $=$ $5.3 \mathrm{~m}$, range: $3.6-9.4 \mathrm{~m})$. Around each individual, the number of conspecifics $\left(N_{i}\right)$ within ring $i$ was counted and the area of the ring within the plot measured $\left(A_{i}\right)$. Densities were computed for each ring $\left(D_{i}\right)$ as $\Sigma N_{i} / \Sigma A_{i}$. The density of conspecifics could then be examined as a function of distance from the average individual. Density values were standardised by dividing them by the average population density at each site, giving $\Omega$.

A value of $\Omega=1$ represents a perfectly random distribution, whereas values greater than one indicate clumping, and those less than one reflect hyperdispersion. Statistical significance of aggregation or overdispersion was determined by checking whether confidence limits (estimated following Condit et al. 2000) included 1.0, and estimates were compared by checking whether confidence limits overlapped. Because the sample plots were relatively small, complicating the calculation of ring area, only distance intervals of $\leq 50 \mathrm{~m}$ were examined.

In a slightly different approach, changes in the distribution of adults and juveniles (grouped in two classes: $<1 \mathrm{~m}$ and $\geq 1 \mathrm{~m}$ in height) with distance from the nearest adult were examined. Any individual that was closer to a boundary of the plot than to its nearest adult was excluded from the analysis, since it might have been closer to an adult outside the plot. If mortality is a random thinning process independent of distance from adults, the distribution of adults along distance intervals should be the same as the distribution of juveniles. In other words, the proportion of adults in a certain distance interval should be equivalent to that of juveniles in the same distance interval. Distance from nearest adult was measured for all individuals that were grouped in concentric $5 \mathrm{~m}$ rings around adult trees, as above. The distribution of the individuals of different size classes among rings was compared using $\chi^{2}$.

\section{Results}

As expected, Eschweilera coriacea was relatively common in all sites (table 1), although population density varied considerably among sites (1,256-4,805 individuals $\left.\mathrm{ha}^{-1}\right)$. Differences between sites in the density of individuals were less apparent when considering the larger size classes compared to smaller individuals. Mature individuals were abundant at all sites with densities of 32-52 ha ${ }^{-1}$. Site $\mathrm{C}_{1} \mathrm{AM}$ had the largest overall population, more than double that of FrMV, and more than three times that of $\mathrm{C}_{2} \mathrm{SM}$. Much of this difference was due to the smallest size class $(\mathrm{dbh}<1 \mathrm{~cm})$, although in the case of $\mathrm{C}_{2} \mathrm{SM}$, numbers were consistently low in most size classes with the exception of the three largest ones. Individuals in the largest size classes ( $\mathrm{dbh}>32 \mathrm{~cm})$ were around twice as abundant at $\mathrm{C}_{1} \mathrm{AM}$ as at the other two sites.
Table 1. Population size structure at each site. Values are the number of individuals sampled in two 1 ha plots per site. The $<1 \mathrm{~cm}$ class includes all individuals $<1 \mathrm{~m}$ in height recorded in transects, scaled to plot size (FrMV = "Fazenda Monte Verde"; $\mathrm{C}_{1} \mathrm{AM}=$ = "Fazenda Amanda"; $\mathrm{C}_{2} \mathrm{SM}=$ "Fazenda São Marcos").

\begin{tabular}{lrrr}
\hline Size class - dbh $(\mathrm{cm})$ & FrMV & C $_{1} \mathrm{AM}$ & $\mathrm{C}_{2} \mathrm{SM}$ \\
\hline$\geq 14$ (adults) & 91 & 99 & 72 \\
$<1$ & 3721 & 8993 & 2256 \\
$\geq 1$ and $<2$ & 111 & 177 & 95 \\
$\geq 2$ and $<4$ & 118 & 206 & 52 \\
$\geq 4$ and $<8$ & 108 & 84 & 27 \\
$\geq 8$ and $<16$ & 72 & 62 & 18 \\
$\geq 16$ and $<32$ & 59 & 42 & 36 \\
$\geq 32$ and $<64$ & 21 & 45 & 27 \\
$\geq 64$ & 2 & 2 & 1 \\
Total & 4212 & 9611 & 2512 \\
\hline
\end{tabular}

Comparing size class structure among the three sites (figure 2), FrMV exhibited a more even distribution than either $\mathrm{C}_{1} \mathrm{AM}$ or $\mathrm{C}_{2} \mathrm{SM}$. The latter two sites also exhibited similar between-plot variation in the smallest size class, which produced significant between-plot differences $\left(\mathrm{C}_{1} \mathrm{AM}: \chi_{2}^{2}=8.600, P=0.014 ; \mathrm{C}_{2} \mathrm{SM}: \chi_{2}^{2}=\right.$ 16.237, $P<0.001$ ), which disappeared when this class was omitted $\left(\mathrm{C}_{1} \mathrm{AM}: \chi_{2}^{2}=0.034, P=0.983 ; \mathrm{C}_{2} \mathrm{SM}: \chi_{2}^{2}=\right.$ $1.216, P=0.545)$. One additional pattern was observed at $\mathrm{C}_{2} \mathrm{SM}$, where there was a dip in the abundance of the intermediate size classes (both plots exhibited the same pattern) (figure 2). Given these differences, size structure distribution patterns differed significantly among all sites (FrM vs. $\mathrm{C}_{1} \mathrm{AM}: \chi_{2}^{2}=25.736, P<0.0001$; FrM vs. $\mathrm{C}_{2} \mathrm{SM}: \chi_{2}^{2}=14.156, P<0.001 ; \mathrm{C}_{1} \mathrm{AM} v s . \mathrm{C}_{2} \mathrm{SM}$ : $\left.\chi_{2}^{2}=8.134, P=0.017\right)$.

The standardised Morisita's index of dispersion tended to vary irregularly with quadrat size, irrespective of size class (figures 3,4 ). In general, adults were less clumped in their distribution than juveniles and the population as a whole at all three sites, although the pattern was least clear at $\mathrm{C}_{2} \mathrm{SM}$. Small juveniles $(<1 \mathrm{~m}$ tall $)$ were more aggregated than larger individuals ( $c f$. figures 3,4 ), and patterns were relatively consistent across sites. There were no significant differences among plots $\left(H_{5}=8.00, P=0.156\right)$ and sites $\left(H_{2}=5.145, P=0.076\right)$ in the dispersion pattern indices for total population $(\geq 1 \mathrm{~m})$, while a significant difference appeared when analysing juveniles of $<1 \mathrm{~m}$ (table 2). In this case, $\mathrm{C}_{1} \mathrm{AM}$ was statistically different from FrMV and $\mathrm{C}_{2} \mathrm{SM}$.

Values of $\Omega$ were relatively close to 1.0 for most distance intervals in all three populations (figure 5). At 

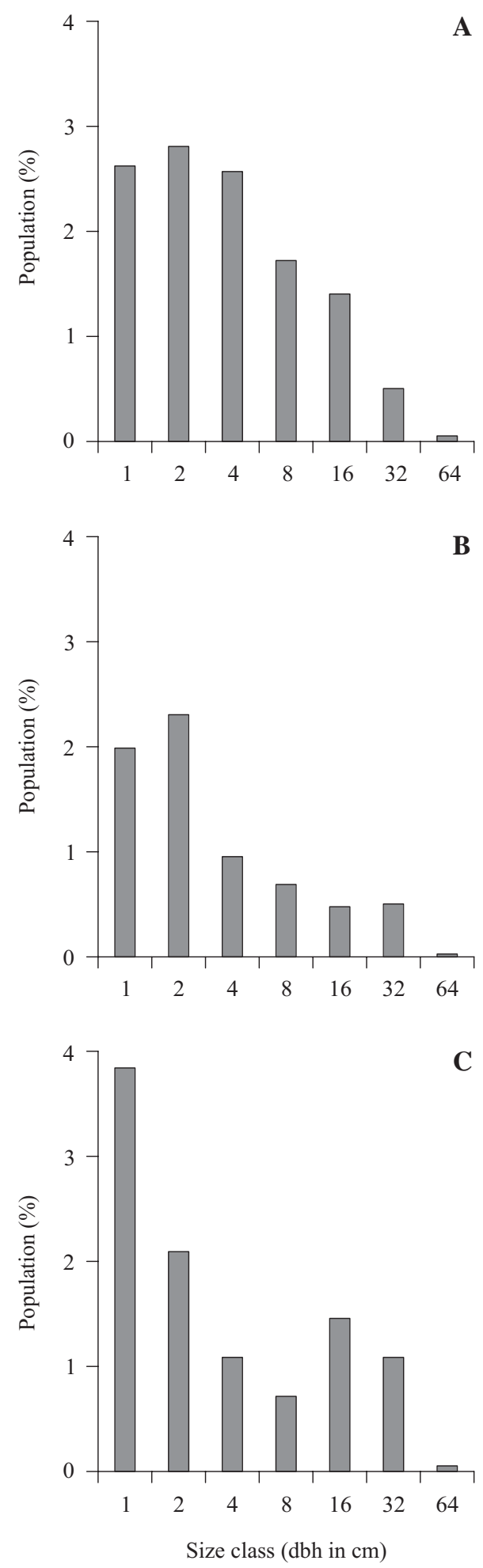

Figure 2. Size structure (percentage of individuals per size class) at the three sites. In order to facilitate visualization, only individuals with $\mathrm{dbh} \geq 1 \mathrm{~cm}$ were plotted, given that smaller individuals constitute $88.3 \%, 93.6 \%$ and $89.8 \%$ of the sample populations at FrMV (A), $\mathrm{C}_{1} \mathrm{AM}(\mathrm{B})$ and $\mathrm{C}_{2} \mathrm{SM}(\mathrm{C})$, respectively. The rest of the population was grouped in doubling size classes (dbh up to $2 \mathrm{~cm}, 4 \mathrm{~cm}, 8 \mathrm{~cm}$...), following Preston (1948, apud Hubbell 2001).
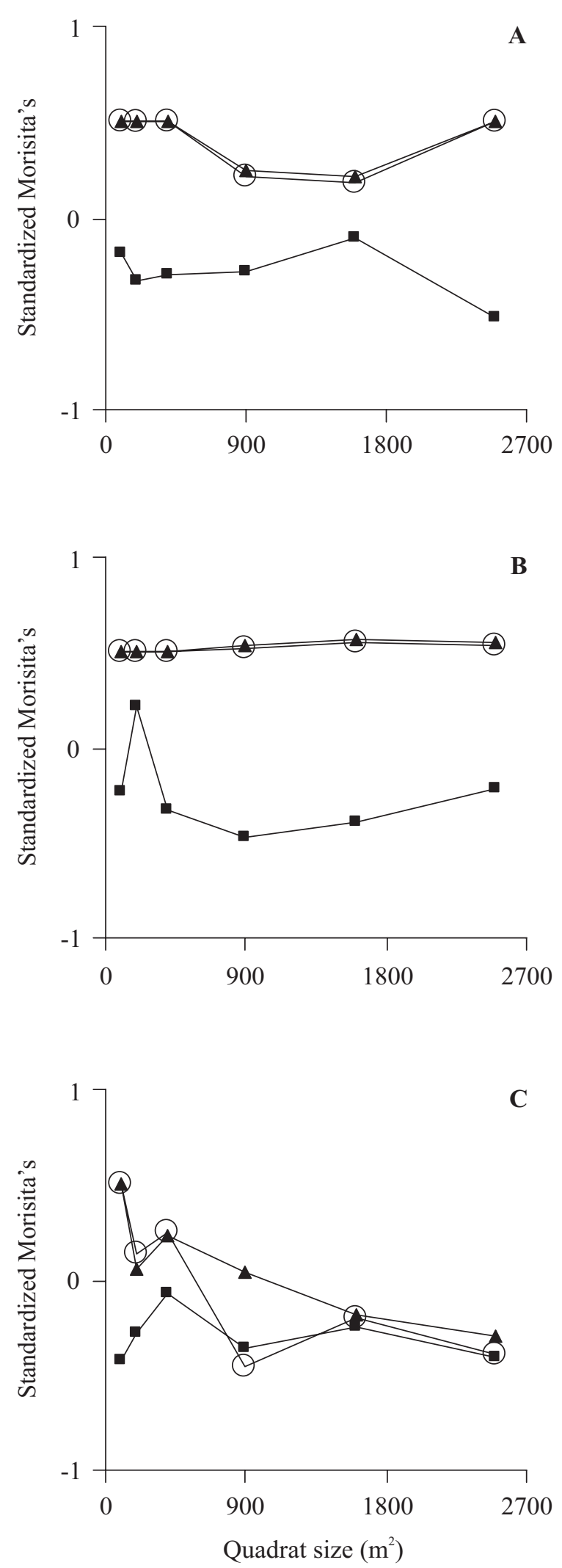

Figure 3. Variation in standardised Morisita's index of dispersion $\left(I_{p}\right)$ with quadrat size for juveniles ( $\geq 1 \mathrm{~m}$ tall), adults and total populations at each site: $\operatorname{FrMV}(\mathrm{A}), \mathrm{C}_{1} \mathrm{AM}(\mathrm{B})$ and $\mathrm{C}_{2} \mathrm{SM}(\mathrm{C})(\boldsymbol{\Delta}=$ juveniles; $\boldsymbol{\square}=$ adults; $\mathrm{o}=$ total population $)$. 
Table 2. Statistical comparison of standardised Morisita's index for juveniles ( $<1 \mathrm{~m}$ tall) among sites and plots (two per site), based on $5-\mathrm{m}^{2}$ quadrats within transects ${ }^{1}$ (FrMV = "Fazenda Monte Verde"; $\mathrm{C}_{1} \mathrm{AM}=$ "Fazenda Amanda"; $\mathrm{C}_{2} \mathrm{SM}=$ "Fazenda São Marcos"; $\mathrm{H}=$ Kruskal-Wallis value; $P$ = probability).

\begin{tabular}{|c|c|c|}
\hline & Plots & Sites \\
\hline $\mathrm{H}$ & 18.052 & 18.046 \\
\hline Degrees of freedom & 5 & 2 \\
\hline$P$ & 0.003 & $<0.001$ \\
\hline \multicolumn{3}{|c|}{$z$ for pairwise comparisons: } \\
\hline FrMV vs. $\mathrm{C}_{1} \mathrm{AM}$ & & $3.444 *$ \\
\hline FrMV vs. $\mathrm{C}_{2} \mathrm{SM}$ & & 0.428 \\
\hline $\mathrm{C}_{1} \mathrm{AM} v s . \mathrm{C}_{2} \mathrm{SM}$ & & $3.872 *$ \\
\hline $\mathrm{FrMV}_{1}$ vs. FrMV 2 & 0.067 & \\
\hline $\mathrm{FrMV}_{1}$ vs. $\mathrm{C}_{1} \mathrm{AM}_{1}$ & 2.421 & \\
\hline $\mathrm{FrMV}_{1}$ vs. $\mathrm{C}_{1} \mathrm{AM}_{2}$ & 2.382 & \\
\hline $\mathrm{FrMV}_{1}$ vs. $\mathrm{C}_{2} \mathrm{SM}_{1}$ & 0.344 & \\
\hline $\mathrm{FrMV}_{1}$ vs. $\mathrm{C}_{2} \mathrm{SM}_{2}$ & 0.328 & \\
\hline $\mathrm{FrMV}_{2}$ vs. $\mathrm{C}_{1} \mathrm{AM}_{1}$ & 2.488 & \\
\hline $\mathrm{FrMV}_{2}$ vs. $\mathrm{C}_{1} \mathrm{AM}_{2}$ & 2.449 & \\
\hline $\mathrm{FrMV}_{2}$ vs. $\mathrm{C}_{2} \mathrm{SM}_{1}$ & 0.278 & \\
\hline $\mathrm{FrMV}_{2}$ vs. $\mathrm{C}_{2} \mathrm{SM}_{2}$ & 0.261 & \\
\hline $\mathrm{C}_{1} \mathrm{AM}_{1}$ vs. $\mathrm{C}_{1} \mathrm{AM}_{2}$ & 0.039 & \\
\hline $\mathrm{C}_{1} \mathrm{AM}_{1}$ vs. $\mathrm{C}_{2} \mathrm{SM}_{1}$ & 2.766 & \\
\hline $\mathrm{C}_{1} \mathrm{AM}_{1}$ vs. $\mathrm{C}_{2} \mathrm{SM}_{2}$ & 2.749 & \\
\hline $\mathrm{C}_{1} \mathrm{AM}_{2}$ vs. $\mathrm{C}_{2} \mathrm{SM}_{1}$ & 2.727 & \\
\hline $\mathrm{C}_{1} \mathrm{AM}_{2}$ vs. $\mathrm{C}_{2} \mathrm{SM}_{2}$ & 2.710 & \\
\hline $\mathrm{C}_{2} \mathrm{SM}_{1}$ vs. $\mathrm{C}_{2} \mathrm{SM}_{2}$ & 0.017 & \\
\hline
\end{tabular}

${ }^{1}$ Critical values of $z$ for the multiple comparison test are 2.936 and 2.394 for $\alpha=0.05$ and $k=6$ and $k=3$, respectively. Statistical significance is indicated by asterisks.

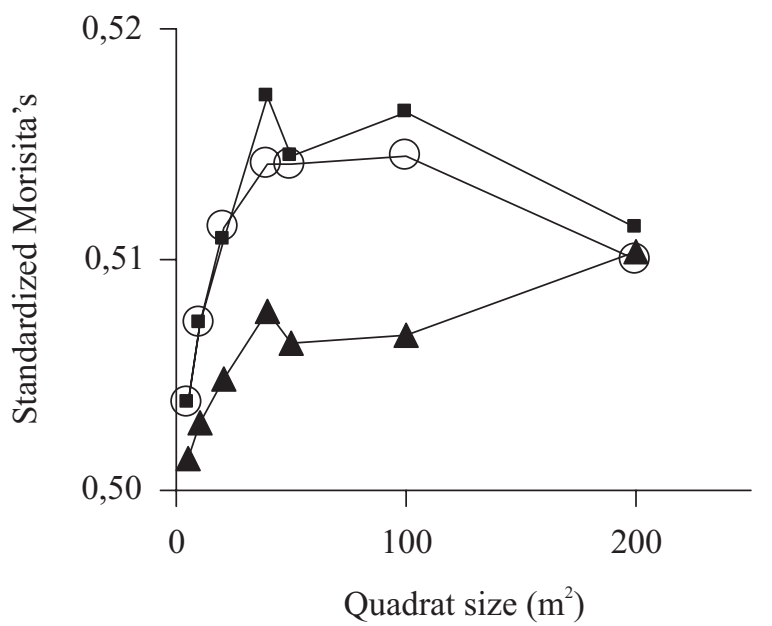

Figure 4. Variation in standardised Morisita's index of dispersion $\left(I_{p}\right)$ with quadrat size for juveniles $<1 \mathrm{~m}$ tall.

$\left(\boldsymbol{\Delta}=\mathrm{FrMV} ; \mathrm{o}=\mathrm{C}_{1} \mathrm{AM} ; \boldsymbol{\square}=\mathrm{C}_{2} \mathrm{SM}\right)$
FrMV and $\mathrm{C}_{2} \mathrm{SM}, \Omega_{0-5}$ was significantly greater than 1.0 for the total population and significantly less than 1.0 for adults, but oscillated around 1.0 in more distant intervals. At $\mathrm{C}_{1} \mathrm{AM}, \Omega$ was significantly greater than 1.0 for the total population in all distance intervals up to $30 \mathrm{~m}$, whereas for adults, $\Omega$ again oscillated around 1.0 . Overall, then, dispersion patterns tend towards randomness, with the most marked differences between adults and total population being found in the first distance interval at all sites. One difference between sites was a tendency towards a more clumped distribution in the population as a whole at $\mathrm{C}_{1} \mathrm{AM}$, in intervals up to $30 \mathrm{~m}$.

Juveniles and adults had different distribution patterns in relation to nearest adults. At FrMV and $\mathrm{C}_{1} \mathrm{AM}$, the smallest juveniles $(<1 \mathrm{~m}$ tall) exhibited a steady decline in abundance from the nearest to the farthest distance interval (figure 6), while at $\mathrm{C}_{2} \mathrm{SM}$, this pattern was obscured by an increase in numbers in the second interval (5-10 m). For the larger juveniles and adults, there was an overall tendency for the number of individuals to peak in this second interval, although once again, there was variation, in particular, a sharp increase in adults in the 15-20 m interval at $\mathrm{C}_{1} \mathrm{AM}$. Distribution patterns were significantly different when small juveniles were compared with both larger juveniles and adults (table 3 ), with the exception of the latter comparison at $\mathrm{C}_{2} \mathrm{SM}$, although even here, $P<0.10$.

Two patterns were clear from these results. Firstly, there did not appear to be a minimum recruitment distance; the smallest juveniles were found in all intervals, together with larger individuals. Secondly, mortality appeared to be higher closer to adults, based on the difference in the distribution of adults and juveniles within distance intervals (figure 6).

\section{Discussion}

Although E. coriacea was a common species at all three study sites, its population density varied up to fourfold among sites. The size class structure of $E$. coriacea at all sites is typical of a species with good regeneration (Hartshorn 1980), although each population exhibited a different structure, reflecting the inherent natural variability resulting from both historical and random factors (Hubbell 2001, Valencia et al. 2004). This population structure patterns, with many individuals in smaller size classes and relatively few in large diameter classes was also found in many of the more common tree species in floodplain forest, Peru (Gentry \& Terborgh 1990), and characterized shade-tolerant species in closedcanopy forest in Barro Colorado Island (BCI), Panama 

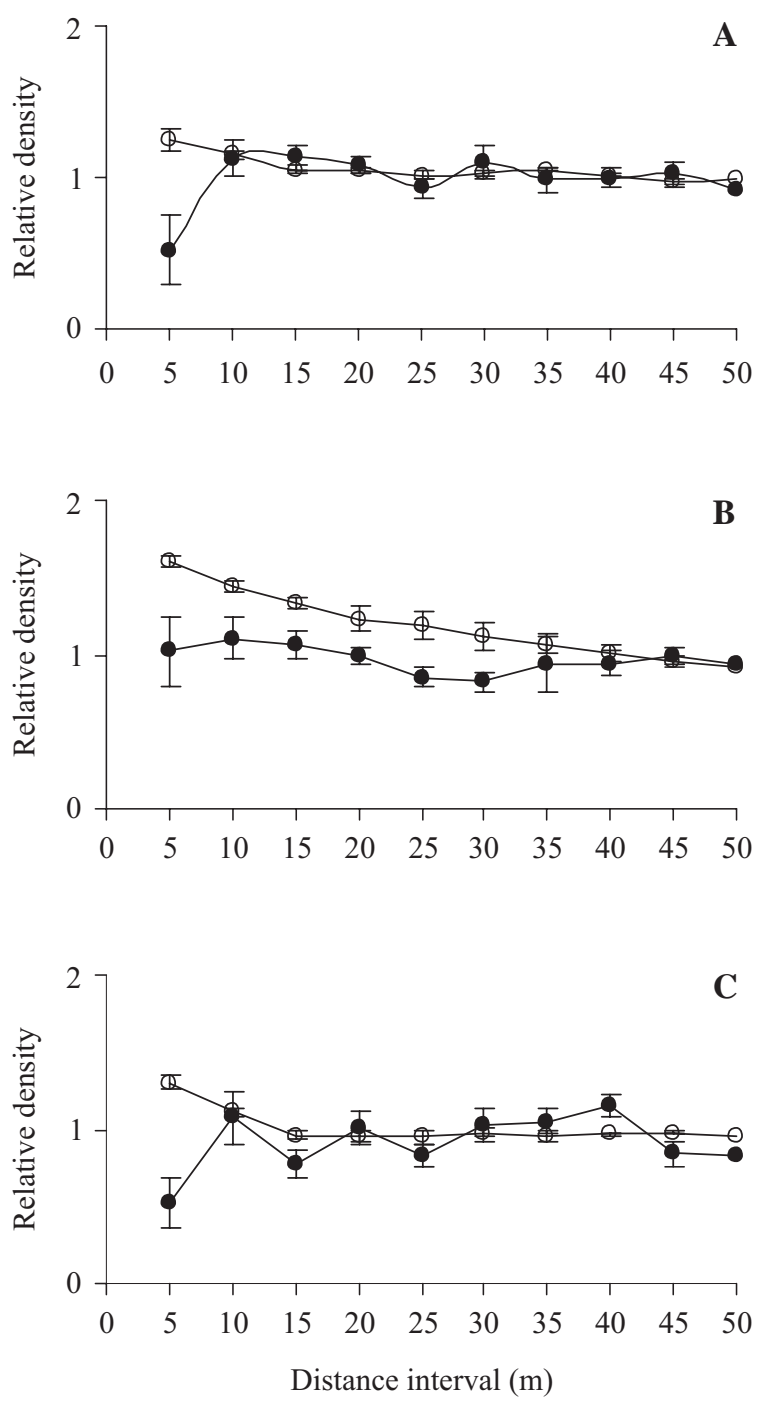

Figure 5. Relative neighbourhood density $(\Omega)$ as a function of distance $(i)$ from the average individual: FrMV (A), $\mathrm{C}_{1} \mathrm{AM}$ (B) and $\mathrm{C}_{2} \mathrm{SM}(\mathrm{C})$. Distance intervals were $5 \mathrm{~m}$-wide concentric rings (0 to $5 \mathrm{~m}, 5$ to $10 \mathrm{~m}$, and so on). Vertical bars represent 95\% confidence limits (see Methods).

( $\mathrm{o}=$ total population; $\bullet=$ adults $)$

(Wright et al. 2003). The cause of the dip in abundance in the medium-size classes at $\mathrm{C}_{2} \mathrm{SM}$ (figure 2 ) is unknown, but it might be related to past logging events, decreasing the number of reproductive individuals by that time. The species has low-quality timber, but is sometimes exploited for fence posts.

Overall, juveniles presented a relatively clumped distribution pattern, whereas adults tended to be randomly distributed. Clumped distribution and relatively short distances among adults were also found in populations of several of the most common species in a dry forest in Costa Rica (Hubbell 1979, 1980), and this was the prevalent pattern found in a study of a Caribbean semi-evergreen
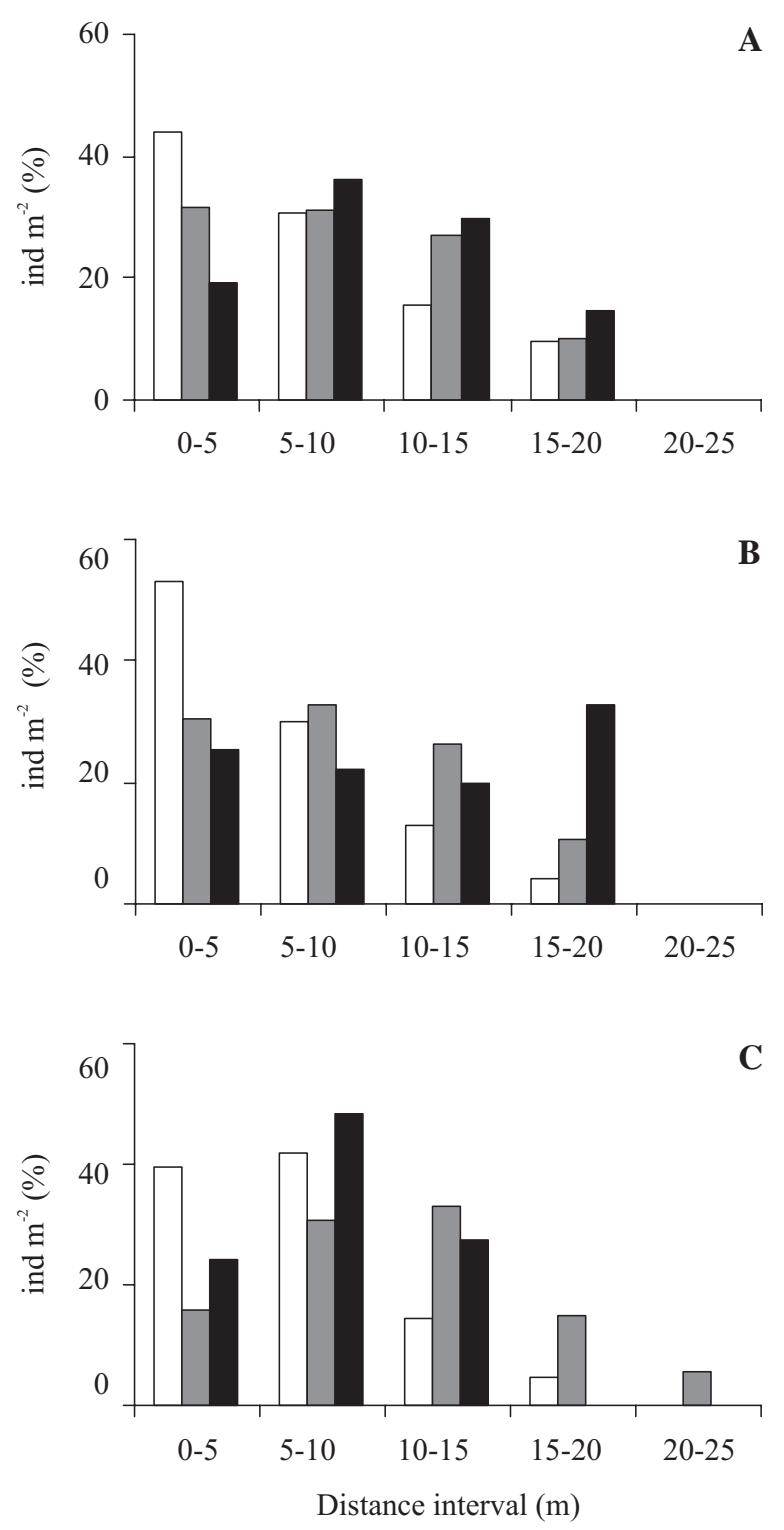

Figure 6. Relative density of individuals of a given size class at different distance intervals in relation to the nearest adult: FrMV (A), $\mathrm{C}_{1} \mathrm{AM}(\mathrm{B})$ and $\mathrm{C}_{2} \mathrm{SM}(\mathrm{C})$. ( $\square=$ juv $<1 \mathrm{~m} ; \square=$ juv $>1 \mathrm{~m}$; $\square=$ adults)

forest (Forman \& Hahn 1980). Other studies of tree species, at least two in Neotropical forests (Henriques \& Sousa 1989, Oliveira Filho et al. 1996) and two in Asia (He et al. 1997, Bunyavejchewin et al. 2003) have also reported decreasing aggregation and increasing randomness from smaller to larger size classes.

The relatively low neighbourhood density $(\Omega)$ values recorded in the present study are similar to those reported by Condit et al. (2000) for the common tree species studied at a number of tropical forest sites such as BCI, in Panama. Hubbell (1979) also found a negative correlation between clumping and population density in Costa Rica. In the present study, however, clumping was stronger 
Table 3. Results of pairwise $\chi^{2}$ tests for comparisons of distribution patterns in relation to nearest adults ${ }^{1}(\mathrm{FrMV}=$ "Fazenda Monte Verde"; $\mathrm{C}_{1} \mathrm{AM}=$ "Fazenda Amanda"; $\mathrm{C}_{2} \mathrm{SM}$ $=$ "Fazenda São Marcos"; $P=$ probability).

\begin{tabular}{|c|c|c|c|}
\hline \multirow{2}{*}{ Small juveniles ${ }^{2} v s$} & \multicolumn{3}{|c|}{$\chi^{2}(P)$ at: } \\
\hline & FrMV & $\mathrm{C}_{1} \mathrm{AM}$ & $\mathrm{C}_{2} \mathrm{SM}$ \\
\hline Adults & $\begin{array}{l}15.913 \\
(0.001)\end{array}$ & $\begin{array}{c}28.169 \\
(<0.0001)\end{array}$ & $\begin{array}{r}47.225 \\
(<0.0001)\end{array}$ \\
\hline Large juveniles $^{2}$ & $\begin{array}{c}16.746 \\
(<0.001)\end{array}$ & $\begin{array}{c}82.374 \\
(<0.0001)\end{array}$ & $\begin{array}{c}4.758^{*} \\
(0.093)\end{array}$ \\
\hline
\end{tabular}

${ }^{1}$ Degrees of freedom $=3$ in all cases, except for $*$, where d.f. $=2$.
${ }^{2}$ Small juveniles $<1 \mathrm{~m}$ tall; large juveniles $\geq 1 \mathrm{~m}$ tall.

where population density was highest, i.e. at $\mathrm{C}_{1} \mathrm{AM}$. Aggregation was also relatively less intense among larger individuals, once again agreeing with Condit et al. (2000). The evidence points to differential mortality in relation to the distance from conspecific adults, supporting the escape hypothesis. Hubbell (1979) did not find evidence of such a difference between adults and juveniles, however.

The most marked differences between adults and the population as a whole were found in the 0-5 m interval at all sites. At both FrMV and $\mathrm{C}_{2} \mathrm{SM}$, adults were significantly hyperdispersed in this interval, compared to significant aggregation in the population as a whole. In the 5-10 m interval, however, the two classes were remarkably similar (figure 5). This pattern is slightly different at $\mathrm{C}_{1} \mathrm{AM}$, where population density was highest overall. This would appear to further support the escape hypothesis. As in the present study, Condit et al. (1992) used $5 \mathrm{~m}$ distance intervals, rather than $10 \mathrm{~m}$, as in Condit et al. (2000). With this smaller distance interval, the authors found the repelled distribution extended for just one crown width for 14 of the 15 species that were repelled from the vicinity of conspecific adults, which is the same pattern I observed for E. coriacea, particularly at FrMV and $\mathrm{C}_{2} \mathrm{SM}$.

Conclusions about the randomness of adult dispersion must be regarded as tentative, however. The adult population of $E$. coriacea may be randomly distributed at the three sites, but it could also be randomly distributed within clumps too large to be detected with the sample plot size used in this study.

Since the youngest plants are mainly the result of recruitment from seeds after the isolation of the forest fragment, the density and dispersion patterns of young juveniles should provide evidence to possible effects of fragmentation on tree regeneration (Harrington et al. 1997). However, none of the differences in abundance and dispersion patterns recorded among sites appears to be related to the forest fragmentation. If the missing mammal species played a significant role in the dispersal of E. coriacea, in their absence young juveniles should be relatively more aggregated. In contrast, young juveniles in plot 2 at FrMV were significantly less aggregated than those at $\mathrm{C}_{1} \mathrm{AM}$ (table 2). It seems either that the original dispersal system of $E$. coriacea did not include the agents that have disappeared from FrMV, or that other agents have taken over their role at this site. Given the abundance and the dispersion pattern of E. coriacea at the three study sites, one could suppose that seeds are dispersed virtually by gravity. Nonetheless, I found evidence of seed dispersal by small rodents at FrMV that deserves future investigations (e.g. seeds of $E$. coriacea far from any fruiting tree around the entrance of a rodent's burrow on the forest floor).

About a third of the tree species at FrMV have less than one individual per hectare and may not be recruiting (Vieira et al. 1996), which may have resulted in an increased availability of regeneration sites for $E$. coriacea. Terborgh (1992) has suggested that escaping predation due to the absence of medium-sized mammals enables large-seeded trees to out-compete other species on small islands in Gatun Lake, Panama. A similar process might be occurring at FrMV.

As the density of new recruits generally tends to be higher closer to adults, the effects of distance and density are correlated (Schupp 1992) and could not be separated in the present analysis. Distance- and density-dependence can regulate populations through intraspecific processes, such as allelopathy or competition, or interspecific interactions, such as seed predation, herbivory and pathogen attack (Howe and Smallwood 1982, Augspurger 1983). Although many studies have found negative effects of population density on different life stages of tropical trees (Harms et al. 2000, Wright 2002), the role of density dependence in the maintenance of the high species diversity in tropical forests remains unclear (Peters 2003). Nevertheless, the identification of density-dependent processes in the present study will hopefully help us to understand the population structure and dynamics of E. coriacea.

Overall, E. coriacea was a common species at all study sites, although population density varied considerably among sites. Regeneration was apparently adequate for the maintenance of populations at all sites, although each population exhibited differences reflecting its specific history, as well as random factors. The dispersion patterns observed at all three sites were relatively clumped for juveniles but random for adults. This suggests differential mortality, in particular in close proximity to adult trees, 
which lends reasonable support to the escape hypothesis (questions 1 and 2). By contrast, differences in juvenile abundance and dispersion patterns among sites could not be related to forest fragmentation (questions 3).

Acknowledgements - I received a partial postgraduate stipend from CAPES. Fieldwork was supported by WWF-Brazil and the Kapok Foundation. I am grateful to T.H. Fleming, C.A. Chapman, D.L. deAngelis, C.C. Horvitz and L.L.S. Sternberg, my supervisory committee at University of Miami, and to S. F. Ferrari for comments on the manuscript. I thank I. Muniz and S. A. da Costa for their assistance. Thanks also to D. Mendonça, S. Elias, M. Elias and T. Magalhães Sobrinho for their hospitality and logistic support.

\section{References}

ALENCAR, A., VIEIRA, I.C.G., NEPSTAD, D.C. \& LEFEBVRE. P. 1996. Análise multitemporal do uso da terra e mudança de vegetação em antiga área agrícola da Amazônia. In Anais do VIII Simpósio Internacional de Sensoriamento Remoto. INPE/MCT/SELPER, Salvador, p.4.

AUGSPURGER, C.K. 1983. Seed dispersal of the tropical tree, Platypodium elegans, and the escape of its seedlings from fungal pathogens. Journal of Ecology 71:759-771.

AYRES, M., AYRES JUNIOR, M., AYRES, D.L. \& DOS SANTOS, A.S. 2005. BioEstat 4.0: Aplicações estatísticas nas áreas das Ciências Biológicas e Médicas. $4^{\text {th }}$ ed., Sociedade Civil Mamirauá, Belém.

BIERREGAARD JUNIOR, R.O., LOVEJOY, T.E., KAPOS, V., DOS SANTOS, A.A. \& HUTCHINGS, R.W. 1992. The biological dynamics of tropical rainforest fragments. Bioscience 42: 859-866.

BUNYAVEJCHEWIN, S., LAFRANKIE, J.V., BAKER, P.J., KANZAKI, M., ASHTON, P.S. \& YAMAKURA, T. 2003. Spacial distribution patterns of the dominant canopy dipterocarp species in a seasonal dry evergreen forest in western Thailand. Forest Ecology and Management 175:87-101.

CLARK, D.A. \& CLARK. D.B. 1984. Spacing dynamics of a tropical forest tree: evaluation of the Janzen-Connell model. American Naturalist 124:769-788.

CLARK, J.S., MACKLIN, E. \& WOOD, L. 1998. Stages and spatial scales of recruitment limitation in southern Appalachian forests. Ecological Monographs 68:213-235.

CONDIT, R., HUBBELL, S.P. \& FOSTER, R.B. 1992. Recruitment near conspecific adults and the maintenance of tree and shrub diversity in a neotropical forest. American Naturalist 140:261-286.

CONDIT, R., ASHTON, P.S., BAKER, P., BUNYAVEJCHEWIN, S., GUNATILLIKE, S., GUNATILLIKE, N., HUBBELL, S.P., FOSTER, R.B., ITOH, A., LAFRANKIE, J.V., LEE, H.S., LOSOS, E., MANOKARAN, N., SUKUMAR, R. \& YAMAKURA, T. 2000. Spatial patterns in the distribution of tropical tree species. Science 288:1414-1418.
CONNELL, J.H. 1971. On the role of natural enemies in preventing competitive exclusion in some marine animals and in rain forest trees. In Dynamics of number in populations (P.J. den Boer \& G.R. Gradwell, eds.). Centre for Agricultural Publishing and Documentation, Wageningen, p.298-312.

CORDEIRO, N.J. \& HOWE, H.F. 2001. Low recruitment of trees dispersed by animals in African forest fragments. Conservation Biology 15:1733-1741.

DINIZ, T.D.A.S. 1986. Caracterização climática da Amazônia oriental. In Pesquisas sobre a utilização e conservação do solo na Amazônia oriental (EMBRAPA/CPATU, org.). Sociedade Alemã de Cooperação Técnica, Belém, p.3-13.

FORMAN, R.T.T. \& HAHN, D.C. 1980. Spatial patterns of trees in a Caribbean semievergreen forest. Ecology 61: 1267-1274.

GARCÍA, D. \& CHARCOFF, N. 2007. Scale-dependent effects of habitat fragmentation on hawthorn pollination, frugivory, and seed predation. Conservation Biology 21:400-411.

GENTRY, A.H. \& TERBORGH, J. 1990. Composition and dynamics of the Cocha Cashu "mature" floodplain forest. In Four Neotropical Forests (A.H. Gentry, ed.). Yale University Press, New Haven, p.542-564.

GUIMARÃES, P.L., FONTINHAS, R.L., ALTIERI, F., SILVA, M.M. \& ANDRADE, V.M.S. 2000. Mapas médios climatológicos do Estado do Pará. In Anais do XI Congresso Brasileiro de Meteorologia. Sociedade Brasileira de Meteorologia, Rio de Janeiro, CD-ROM.

GUIMARÃES, P.L., FONTINHAS, R.L., OLIVEIRA, L.L. \& BARRETO, N.J.C. 2001. Mapa de classificação climática do Estado do Pará. In Anais do III Congresso Brasileiro de Biometeorologia. Sociedade Brasileira de Biometeorologia, Maringá, CD-ROM.

HARMS, K.E., WRIGHT, S.J., CALDERÓN, O., HERNÁNDEZ, A. \& HERRE, E.A. 2000. Pervasive density-dependent recruitment enhances seedling diversity in a tropical forest. Nature 404:493-495.

HARRINGTON, G.N., IRVINE, A.K., CROME, F.H.J. MOORE, L.A. 1997. Regeneration of large-seeded trees in Australian rainforest fragments: a study of higher-order interactions. In Tropical forest remnants: ecology, management, and conservation of fragmented communities (W.F. Laurance \& R.O. Bierregaard Junior, eds.). University of Chicago Press, Chicago, p.292-303.

HARTSHORN, G.S. 1980. Neotropical forest dynamics. Biotropica 12:23-30.

HE, F., LEGENDRE, P. \& LAFRANKIE, J.V. 1997. Distribution patterns of tree species in a Malaysian tropical rain forest. Journal of Vegetation Science 8:105-114.

HENRIQUES, R.P.B. \& SOUSA, E.C.E.G. 1989. Population structure, dispersion and microhabitat regeneration of Carapa guianensis in northeastern Brazil. Biotropica 21:204-209.

HOWE, H. F. \& SMALLWOOD, J. 1982. Ecology of seed dispersal. Annual Review of Ecology and Systematics 13:201-228. 
HUBBELL, S.P. 1979. Tree dispersion, abundance, and diversity in a tropical dry forest. Science 203:1299-1309.

HUBBELL, S.P. 1980. Seed predation and the coexistence of tree species in tropical forest. Oikos 35:214-229.

HUBBELL, S.P. 2001. The unified neutral theory of biodiversity and biogeography. Monographs in Population Biology 32. Princeton University Press, Princeton.

JANZEN, D.H. 1970. Herbivores and the number of tree species in tropical forest. American Naturalist 104:501-528.

KREBS, C.J. 1999. Ecological Methodology. $2^{\text {nd }}$ ed., Benjamin/ Cummings, Menlo Park.

LAURANCE, W.F., FERREIRA, L.V., RANKIN-DEMERONA, J.M., LAURANCE, S.G., HUTCHINGS, R. \& LOVEJOY, T.E. 1998. Effects of forest fragmentation on recruitment patterns in Amazonian tree communities. Conservation Biology 12:460-464.

LAURANCE, W.F., LOVEJOY, T.E., VASCONCELOS, E.M.B., DIDHAM, R.K., STOUFFER, P.C., GASCON, C., BIERREGAARD, R.O., LAURANCE, S.G. \& SAMPAIO, E. 2002. Ecosystem decay of Amazonian forest fragments: a 22-year investigation. Conservation Biology 16:605618.

LINDENMAYER, D.B., CUNNINGHAM, R.B., DONNELLY, C.F., NIX, H. \& LINDENMAYER, D.B.D. 2002. Effects of forest fragmentation on bird assemblages in a novel landscape context. Ecological Monographs 72:1-18.

LOPES, M.A. \& FERRARI, S.F. 2000. Effects of human colonization on the abundance and diversity of mammals in eastern Brazilian Amazonia. Conservation Biology 14:1658-1665.

MORI, S.A. \& PRANCE, G.T. 1990. Lecythidaceae-Part II. The zygomorphic-flowered new world genera. Series Flora Neotropica, monograph 21. The New York Botanical Garden, New York.

NATHAN, R.R. \& CASAGRANDI, R. 2004. A simple mechanistic model of seed dispersal, predation and plant establishment: Janzen-Connell and beyond. Journal of Ecology 92:733-746.

NELSON, B.W. \& OLIVEIRA, A.A. 2001. Área botânica. In Biodiversidade na Amazônia brasileira - avaliação e ações prioritárias para a conservação, uso sustentável e repartição de benefícios (A. Veríssimo, A. Moreira, D. Sawyer, I. Santos \& L.P. Pinto, orgs.). New York Botanical Garden, New York, p.132-176.

OLIVEIRA FILHO, A.T., CAMISÃO-NETO, A.A. \& VOLPATO, M.M.L. 1996. Structure and dispersion of four tree populations in an area of montane semideciduous forest in southeastern Brazil. Biotropica 28:762-769.

OLIVEIRA, L.L., FONTINHAS, R.L., LIMA, A.M.M. \& LIMA, R.J.S. 2002. Mapas dos parâmetros climatológicos do Estado do Pará: umidade, temperatura e insolação, médias anuais. In Anais do XIII Congresso Brasileiro de Meteorologia. Sociedade Brasileira de Meteorologia, Fortaleza, CD-ROM.
PEREIRA, A.P.C.P. 2002. Ecologia alimentar do cuxiú-preto (Chiropotes satanas satanas) em um fragmento de floresta de terra firme do leste do Pará. Tese de mestrado, Universidade Federal do Pará, Belém.

PETERS, H.A. 2003. Neighbour-regulated mortality: the influence of positive and negative density dependence on tree populations in species-rich tropical forests. Ecology Letters 6:757-765.

PIRES, J.M. \& PRANCE, G.T. 1977. The Amazon forest: a natural heritage to be preserved. In Extinction is forever: the status of threatened and endangered plants of the Americas (G.T. Prance \& T.S. Elias, eds.). New York Botanical Garden, New York, p.158-194.

PRANCE, G.T. 1989. American tropical forests. In Tropical rain forest ecosystems (H. Lieth \& M.J.A. Werger, eds.). Elsevier Science Publishers B.V., Amsterdam, p.99-132.

PRANCE, G.T. \& MORI, S.A. 1978. Observations on the fruits and seeds of neotropical Lecythidaceae. Brittonia 30: 21-33.

SCHUPP, E.W. 1992. The Janzen-Connell model for tropical trees diversity: population implications and the importance of spatial scale. American Naturalist 140:526-530.

SILVA, B.N.R. \& CARVALHO, J.S. 1986. Os solos da Amazônia oriental. In Pesquisas sobre a utilização e conservação do solo na Amazônia oriental (Embrapa/Cpatu, org.). Sociedade Alemã de Cooperação Técnica, Belém, p. $15-42$.

SOKAL, R.R. \& ROHLF, F.J. 1995. Biometry - the principles and practice of statistics in biological research. $3^{\text {rd }}$ ed., W.H. Freeman \& Company, New York.

SUDAM. 1984. Atlas climatológico da Amazônia brasileira. Publicação 39, Belém.

TABARELLI, M., MANTOVANI, W. \& PERES, C.A. 1999. Effects of habitat fragmentation on plant guild structure in the montane Atlantic forest of southeastern Brazil. Biological Conservation 91:119-127.

TERBORGH, J. 1992. Maintenance of diversity in tropical forests. Biotropica 24:283-292.

TURNER, I. M. \& CORLETT, R.T. 1996. The conservation value of small, isolated fragments of lowland tropical rain forest. Trends in Ecology and Evolution 11:330-333.

VALENCIA, R., FOSTER, R.B., VILLA, G., CONDIT, R., SVENNINGS, J.C., HÉRNANDEZ, C., ROMOLEROUX, K., LOSOS, E., MAGÅRDS, E. \& BALSLEV, H. 2004. Tree species distributions and local habitat variation in the Amazon: large plot in eastern Ecuador. Journal of Ecology 92:214-229.

VELOSO, H.P., RANGEL FILHO, A.L.R. \& LIMA, J.C.A. 1991. Classificação da vegetação brasileira, adaptada a um sistema universal. Derna/Ibge, Rio de Janeiro.

VIEIRA, I.C.G., SALOMÃO, R.P., ROSA, N.A., NEPSTAD, D.C. \& ROMA, J. 1996. O renascimento da floresta no rastro da agricultura. Revista Ciência Hoje 119:38-44.

WRIGHT, S.J. 2002. Plant diversity in tropical forest: a review of mechanisms of species coexistence. Oecologia 130:1-14. 
WRIGHT, S.J. \& DUBER, H.C. 2001. Poachers and forest fragmentation alter seed dispersal, seed survival, and seedling recruitment in the palm Attalea butyraceae, with implications for tropical tree diversity. Biotropica 33:583-595.
WRIGHT,S.J.,MULER-LANDAU,H.C.,CONDIT,R.\&HUBBELL, S.P. 2003. Gap-dependent recruitment, realized vital rates, and size distributions of tropical trees. Ecology 84:3174-3185. ZAR, J.H. 1999. Biostatistical analysis. $4^{\text {th }}$ ed., Prentice-Hall, Upper Saddle River. 